\title{
1 Aspects of resilience of polar sea ice algae to changes in their environment
}

2 Meghana A. Rajanahally ${ }^{1}$, Phil J. Lester ${ }^{1} \&$ Peter Convey ${ }^{1,2 *}$

$3{ }^{1}$ School of Biological Sciences, Victoria University of Wellington, PO Box 600, Wellington

$4 \quad 6140$, New Zealand

$5{ }^{2}$ British Antarctic Survey, NERC, High Cross, Madingley Road, Cambridge CB3 0ET,

6 United Kingdom

$7 \quad$ * corresponding author: meghana.rajanahally@gmail.com (0061 434965 885)

\section{Abstract}

10 Sea ice algae are the primary producers of the ice-covered oceans in both polar regions.

11 Changes in sea ice distribution are potentially altering exposure to photosynthetically active

12 (PAR) and ultra-violet (UV-B) wavelengths of light. Incubations using monospecific cultures

13 of common species from the Ross Sea, Antarctic Peninsula and Arctic Ocean were carried out at ecologically relevant light levels over periods of $7 \mathrm{~d}$ to examine their tolerance to conditions likely to be faced during sea ice thinning and melt. Algal responses were assessed using chlorophyll fluorescence techniques and superoxide dismutase activity. Quantum yields

17 of cultures incubated in the dark and at ambient light did not differ. At higher light levels, the Ross Sea and Arctic cultures showed no significant change in photosynthetic health, while those from the Antarctic Peninsula showed a significant decrease. Antarctic cultures showed no detectable changes in superoxide dismutase activity, while the Arctic culture showed dynamic changes, initially increasing, then decreasing to the end of the study. The general lack of significant changes signals the need for further parameters to be assessed during such 
24 photosynthetic health, even though significant effects have been detected in other studies

25 when subjected to PAR or UV-B alone.

26

27 Key words: Sea ice algae, Thalassiosira antarctica, Chaetoceros socialis, photoprotection,

28 stress, ultra-violet B, Ross Sea, Antarctic Peninsula, Arctic Ocean

29

30 
Polar sea ice forms one of the largest ecosystems on Earth. In the Antarctic it covers an area of $19 \times 10^{6} \mathrm{~km}^{2}$ at its maximum extent in winter, diminishing to $3 \times 10^{6} \mathrm{~km}^{2}$ during the summer (Arrigo, 2014). In the Arctic it oscillates between 15 and $5 \times 10^{6} \mathrm{~km}^{2}$. The long-term rate of change is currently greater in the Arctic, where summer ice extent has reduced by $45 \%$ in only the past three decades and, in areas of rapid sea ice decrease, the spring retreat now initiates two months earlier and autumn advance one month later as compared to 1979/1980, resulting in the ice-free summer season lengthening by three months (Maksym et al., 2012; Stammerjohn et al., 2012). In the Antarctic overall winter sea ice extent has slightly increased (Turner et al., 2013; http://www.ipcc.ch/report/ar5/wg1/\#.UuhKY2SBoYI) but its distribution has changed, with increases in the Ross Sea region and decreases in the Weddell Sea (Arrigo, 2014; Turner et al., 2013). In the Antarctic Peninsula and Bellinghausen Sea region, changes in sea ice retreat and advance timing have again led to a three month longer ice-free period (Stammerjohn et al., 2012). In contrast, in the Ross Sea region, sea ice retreat is one month later and advance is one month earlier, leading to a shortening of the summer ice-free season by almost two months. Such changes in sea ice duration and distribution can cause severe ecological disruptions, with potentially negative consequences for the whole ecosystem (Arrigo, 2014; Nicol et al., 2008).

Sea ice algal communities reach their peak standing biomass in spring, leading to a significant increase in pigment concentration in the ice (Arrigo, 2014). This reduces the amount of light available to the upper water column, affecting algal productivity in the water below the ice (Arrigo et al., 1991; SooHoo et al., 1987). Phytoplankton blooms in the water column are delayed until after the ice algal bloom, whose timing therefore controls that of the subsequent phytoplankton bloom (Arrigo et al., 2012). When the sea ice melts, some of the algae released can provide seed stock for blooms at the ice edge (Cunningham \& Leventer, 
1998; Mangoni et al., 2009), as well as in the benthic and epiphytic habitats beneath

(Majewska et al. 2013). However, this depends on their surviving the melting transition and acclimating very rapidly to the higher photosynthetically active radition (PAR) and ultraviolet-B (UV-B) conditions that they are then exposed to (Mundy et al., 2011), and not being lost through sedimentation (Riebesell et al., 1991).

Sea ice can form annually, or survive to become thicker multi-year ice (Arrigo \& Thomas, 2004) through which light transmission is reduced. Snow cover, and its changing patterns, can further influence the under-ice environment (Arrigo, 2014). An emigration of diatoms from Arctic sea ice has been reported under thickness reducing conditions that could lead to reductions in productivity from the ice algal bloom, thereby impacting overall productivity (Lund-Hansen et al., 2013).

Microalgae are the primary producers found in the complex sea ice ecosystem, with diatoms (Bacillariophyceae) dominating (Arrigo, 2014) and reaching large stocks in the Antarctic due to the nutrient-rich waters of the Southern Ocean. The potential for nutrient limitation in the Antarctic is considered to be low, but local depletion can occur if there are other growthlimiting factors (Harrison \& Cota, 1991) such as vertical stratification in the water column and depletion due to the sea ice algal bloom in spring. In both the Antarctic and Arctic factors other than nutrients, such as light and salinity, can also be limiting (Harrison \& Cota, 1991). Algal cell concentrations in sea ice can vary by up to six orders of magnitude $\left(<10^{4}\right.$ to $>10^{9}$ cells $1^{-1}$; Arrigo et al., 2010), a range that covers both typical global oceanic values and some of the highest recorded in any aquatic environment. Chlorophyll $a(\mathrm{Chl} a)$ biomass in sea ice varies by region, ice type and season. In the Arctic, volumetric Chl $a$ concentrations range from 3 to $800 \mathrm{mg} \mathrm{m}^{-3}$, and they can reach 10,100 $\mathrm{mg} \mathrm{m}^{-3}$ in the Antarctic (Arrigo et al., 2010). The higher values in the Antarctic are again related to greater nutrient availability, and to lower annual light levels at the highest latitudes in the Arctic. 
81 The community composition of the sea ice and associated ecosystems is determined by physical factors including light, salinity, nutrients and temperature (Arrigo \& Thomas, 2004; Arrigo et al., 2010; Arrigo, 2014). Specific communities can include 30-170 diatom species. Commonly encountered genera in land-fast ice include Nitzchia, Thalassiosira, Fragilariopsis and Navicula. Microlagal biomass varies through the sea ice profile, with the highest levels found in the bottom $20 \mathrm{~cm}$ due to the stable light and temperature conditions present in this part of the sea ice (Arrigo \& Thomas, 2004). There is also a constant supply of nutrients to this bottom layer through its interface with the underlying seawater (Arrigo, 2014). Microalgal blooms in the sea ice are short-lived and are limited by low light and low temperatures (Ratkova et al., 2004). The distribution of algal biomass can also be patchy and show large variability (Rysgaard et al., 2001) due to local conditions such as surface snow cover and strong sub-ice water currents (Lund-Hansen et al., 2013).

Various studies have examined the effects of particular environmental parameters on monospecific cultures (e.g. Davidson et al., 1994; Hannach \& Sigleo, 1998; Leu et al., 2010; Martin et al., 2012; Ryan et al., 2012). However, very few have examined the effect of multiple stressors (Halac et al., 2010; Hancke et al., 2008; Petrou et al., 2011; Salleh \& McMinn, 2011) or compared common algal species from different parts of the polar regions (Petrou \& Ralph, 2011). Brief periods of exposure to high light levels caused significant changes to the photosynthetic activity and composition (affecting its quality as a dietary item) of a common polar microalga, Thalassiosira antarctica var. borealis (Leu et al., 2006). Exposure to higher PAR and UVR caused a decline in the quantum yield of photosystem II (PSII) and led to a significant reductions in $\mathrm{C}: \mathrm{P}$ and $\mathrm{N}: \mathrm{P}$ ratios. There was also a difference in the effects of PAR and UVR, with the algae affected strongly by increase in PAR but not UVR. 
Ultra-violet radiation (UVR) reduces photo-protective capacity in diatoms such as

Phaedactylum tricornutum (Halac et al., 2009), affecting the xanthophyll cycle and causing a

decrease in photosynthetic health when exposed to saturating PAR. However, Halac et al. (2010) also demonstrated how increased temperature could counteract the negative effects of UVR, as well as variation in response due to length of exposure and size of cells, highlighting the importance of studying species-specific responses. High PAR and UVR stress can also lead to detrimental photoreactions (Janknegt et al., 2007), interrupting important metabolic pathways and causing an over-reduction of the electron transport chain (ETC). When this occurs, electrons from the ETC combine with molecular $\mathrm{O}_{2}$ leading to the formation of reactive oxygen species (ROS). ROS cause damage to photosystem II reaction center proteins, thereby reducing the photosynthetic rate (Van De Poll et al., 2005). In response to this damage, cells produce antioxidant enzymes that actively scavenge ROS intermediates. The first ROS produced is a superoxide anion $\left(\mathrm{O}_{2}{ }^{\bullet-}\right)$, which can be converted into the highly active hydroxyl radical $\left(\mathrm{HO}^{\bullet}\right)$ through a series of reductions. To avoid this, $\mathrm{O}_{2}{ }^{\bullet}$ is converted describe SOD responses in marine polar microalgae are rare due to difficulties such as obtaining sufficient biomass for reliable measurements (Janknegt et al., 2009; Katayama \& Taguchi, 2013; Van de Poll et al., 2009).

The primary aims of the current study were (1) to examine the photosynthetic (measured using chlorophyll fluorescence techniques) and antioxidative (measured using the RF/NBT assay) responses of sea ice algae in laboratory treatments combining ecologically relevant PAR and UV-B exposures, in order to study the capacity of common species to tolerate increased radiation levels such as might be experienced during ice melt and the thinning of sea ice, and (2) to compare acclimatory abilities across species. The study used monospecific 
cultures of common algal species obtained from three regions with different patterns of environmental variation, namely the Ross Sea, the Antarctic Peninsula and the Arctic Ocean. Assessing the capacity of these algae for photo-protection will provide a better foundation for predictions relating to their response in context of climate change.

\section{Methods}

\section{Culture methodology}

Monospecific stock cultures were maintained in Victoria University of Wellington at a PAR level of $50 \mu \mathrm{mol} \mathrm{m} \mathrm{s}^{-1}$ and $4{ }^{\circ} \mathrm{C}$ in $\mathrm{f} / 2$ medium (Ausaqua Pty Ltd., Australia) for 5-6 months prior to these experiments. The Ross Sea species, Thalassiosira antarctica, used in the experiments described below were isolated from sea ice at Cape Evans in the summer of 2010/2011. A stock culture of Chaetoceros socialis from the Antarctic Peninsula was obtained from Dr. Claire Hughes (University of East Anglia) as part of studies under the Rothera Time Series maintained by the British Antarctic Survey near its Rothera Research

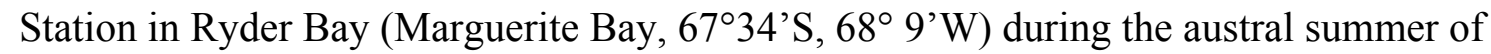
2008/2009 (http://www.antarctica.ac.uk//staff-profiles/webspace/mmm/RaTS/RaTS.html). A stock culture of the same nominate species from the Arctic was obtained from Assoc. Prof. Else Hegseth (University of Tromso), originally collected from Billefjorden, Svalbard, in summer 2011.

\section{$\underline{\text { Light treatments }}$}

The light treatments were based on measurements taken in the field in the Ross Sea through the sea ice profile (MAR pers. obs.; see also Rajanahally et al., 2014) and are representative of the PAR and UV- B levels that sea ice algae would be exposed to from the middle to the bottom of the sea ice profile (Eicken, 1992; Petrou \& Ralph, 2011; Rajanahally et al., 2014; 
154 Ryan et al., 2011). Sub-samples (400 ml) of monospecific cultures ( $\mathrm{n}=3$ at each level) were 155 incubated under each of four light levels ( $\mathrm{L} 0=0 \mu \mathrm{mol} \mathrm{m} \mathrm{m}^{-2}, \mathrm{~L} 1=1 \mu \mathrm{mol} \mathrm{m} \mathrm{s}^{-1}$ of PAR, $156 \mathrm{~L} 2=45 \mu \mathrm{mol} \mathrm{m} \mathrm{s}^{-1}$ of PAR and $50 \mathrm{~mW} \mathrm{~m}^{-2}$ of UV-B, L3 $=100 \mu \mathrm{mol} \mathrm{m}^{-2} \mathrm{~s}^{-1}$ of PAR and 50 $157 \mathrm{~mW} \mathrm{~m}{ }^{-2}$ of UV-B) at $4{ }^{\circ} \mathrm{C}$ for $168 \mathrm{~h}$ in a temperature controlled water bath (Haake, Cleveland, $158 \mathrm{OH}, \mathrm{USA})$. These light levels are intended to be representative of those found in the water column below the sea ice (L0), at the bottom of the sea ice (L1), a quarter of the way above 160 the water-ice interface (L2), or at the middle of the sea ice profile (L3). The separate PAR and UV-B levels were combined to reflect that the increase in PAR is synchronous with an increase in UV-B through the sea ice profile.

The $400 \mathrm{ml}$ samples were incubated following standard approaches described by Ryan et al. (2012) in $500 \mathrm{ml}$ opaque containers which were placed under 5W LED lights (Greenlights, Taiwan) and a Philips Ultraviolet-B TL 12/40W UV-B tube. Different sections of the water bath were separated from each other with opaque black plastic sheets and the various levels of light and UV-B were obtained with appropriate shade cloth. The UV-B tube was also covered with a polyvinyl chloride (PVC) sheet to filter out harmful UV-C radiation. PAR levels were measured using a SpectroSense 2 meter with an SKR 1850 radiometer (bandwith $400-700 \mathrm{~nm}$ ) and UV-B with an SKU 430 broad band UV-B radiometer (bandwidth 280 $315 \mathrm{~nm})$ (Skye Instruments, UK).

172 Samples of $1 \mathrm{ml}$ for cell counts were taken at 0,48 and $168 \mathrm{~h}$ from all replicates in each incubation, preserved using $2 \%$ Lugol's Iodine and stored at $4{ }^{\circ} \mathrm{C}$. Fifty $\mathrm{ml}$ of sample was used for the measurement of MAA content following the protocol described by Ryan et al. (2002) and Rajanahally et al. (2014). However, as no detectable amounts of MAAs were 176 produced, no further consideration of MAAs is included here.

\section{Chlorophyll $a$ content}


Twenty-five $\mathrm{ml}$ of sample were used for the measurement of chlorophyll $a$ content. This was

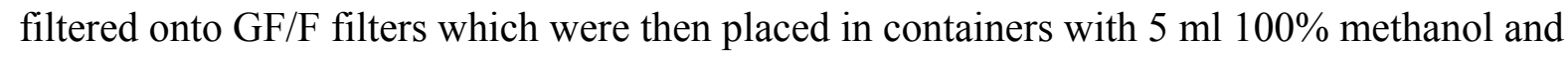
extracted in the dark at $4^{\circ} \mathrm{C}$ for $24 \mathrm{~h}$. The extract was then measured on a digital fluorometer (Turner 10AU, Australia) following the acidification method of Evans et al. (1987).

\section{$\underline{\text { Superoxide dismutase activity }}$}

Twenty to $80 \mathrm{ml}$ of the sample was stored in a container at $-20^{\circ} \mathrm{C}$ for measurement of superoxide dismutase (SOD) activity following Janknegt et al. (2007). The variation in volumes collected for determination of SOD activity was due to varying growth rates between species. As SOD activity had not been previously determined for these cultures, it was not possible to identify the minimum volume required a priori. Therefore, a minimum of $20 \mathrm{ml}$ and, in some cases, a larger volume was collected as a contingency to ensure the level of SOD activity was assayable. These samples were centrifuged $\left(2000 \mathrm{xg}, 5 \mathrm{~min}, 4^{\circ} \mathrm{C}\right)$ in 1 $\mathrm{ml}$ Eppendorf tubes and the pellets were stored at $-80^{\circ} \mathrm{C}$ to preserve enzyme activity.

For enzyme measurements, cell pellets were thawed on ice, centrifuged (2000 x g, 5 min, $4^{\circ} \mathrm{C}$ ) and resuspended in $1 \mathrm{ml}$ cold lysis buffer mixture of $300 \mu 1$ potassium phosphate buffer (50 mM, pH 7.8) containing DTPA $(0.2 \mathrm{mM})$, riboflavin $(1.3 \mu \mathrm{M})$, L-methionine (10 mM), NBT $(57 \mu \mathrm{M})$, and Triton X-100 $(0.025 \%(\mathrm{v} / \mathrm{v}))$. The suspension was then centrifuged $(2000$ $\mathrm{x} \mathrm{g}, 5 \mathrm{~min}, 4^{\circ} \mathrm{C}$ ) again before the cells were resuspended in a final volume of $500 \mu 1$ of lysis buffer and sonicated (Ultrasonic liquid processor W-380, Heat Systems-Ultrasonics, Inc., New York) on ice for three $15 \mathrm{~s}$ pulses with a time interval of $10 \mathrm{~s}$ between each pulse. All lysates were centrifuged $\left(16000 \mathrm{x} \mathrm{g}, 5 \mathrm{~min}, 4^{\circ} \mathrm{C}\right)$ and supernatants aliquoted and frozen at $80^{\circ} \mathrm{C}$ until further analysis. Total aqueous soluble protein content was determined using the improved Bradford assay with BSA as standard (Zor \& Selinger, 1996). 
SOD assays were performed using the riboflavin/nitroblue tetrazolium (RF/NBT) assay in a of lysate or SOD standard $\left(0.5-500 \mathrm{U} \mathrm{ml}^{-1}\right)$ were added into a final reaction mixture of $300 \mu \mathrm{l}$ potassium phosphate buffer $(50 \mathrm{mM}, \mathrm{pH} 7.8)$ containing EDTA $(0.1 \mathrm{mM})$, riboflavin $(1.3$ $\mu \mathrm{M})$, L-methionine $(10 \mathrm{mM})$, NBT $(57 \mu \mathrm{M})$, and Triton X-100 (0.025\% (v/v)). Absorbance was read at $560 \mathrm{~nm}$ both immediately and after $10 \mathrm{~min}$ incubation under a homogenous light field $\left(130 \mu \mathrm{mol} \mathrm{m} \mathrm{m}^{-1}\right)$ at $25^{\circ} \mathrm{C}$. Standards and samples were measured using the same reaction mixture and a sigmoidal 5-parameter semi logarithmic standard curve (24 standard levels) used to determine SOD activity of samples. One unit of SOD activity was defined as the amount of enzyme that inhibited the NBT reduction by 50\% (Beyer \& Fridovich, 1987).

\section{$\underline{\text { Sub-sampling, PAM fluorometry, and statistical analyses }}$}

PAM fluorometry is a widely used tool for studying the photosynthetic health of microalgae (Hancke et al., 2008; Katayama \& Taguchi, 2013; McMinn \& Hegseth, 2004; Parkhill et al., 2001; Ryan et al., 2009) as it provides a non-invasive method to study smaller cultures. A Water PAM fluorometer (Walz, Effeltrich, Germany) was used to measure effective quantum yield for photosystem II ( $\phi$ PSII). Before commencing observations, the cells were dark acclimated. Thereafter, all PAM measurements were made on cells exposed to light as the cells were subjected to actinic light used to make the PAM measurements. The Water PAM was also used to generate rapid light curves (RLC). An RLC describes the effective quantum yield as a function of irradiance (Ralph \& Gademann, 2005). Each sample was treated with a series of eight increasing actinic light treatments $\left(0,8,20,35,55,75,96,114,150 \mu \mathrm{mol} \mathrm{m} \mathrm{m}^{-2}\right.$ $\mathrm{s}^{-1}$ ), after which a strong saturating pulse was applied and $\phi$ PSII was recorded. The RLC took $90 \mathrm{~s}$ to generate. The electron transport rate (ETR) values were calculated by multiplying the

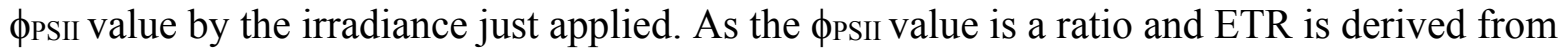


this parameter, it is termed relative ETR (rETR). An RLC permits derivation of different parameters that can be used to describe the photosynthetic properties of an algal sample, including rETRmax (the maximum value for rETR), photosynthetic efficiency $(\alpha)$ and saturation irradiance $\left(E_{\mathrm{k}}\right)$ (Ryan et al., 2009). To determine these parameters, the rETR data were imported into Microsoft Excel v 10.0 (Microsoft, USA) and the curve was fitted with a "waiting-in-line" function as described by Ritchie (2008). An RLC was generated for each sample at times $0,2,4,6,12,24,48,72,96,120,144$ and $168 \mathrm{~h}$.

\section{$\underline{\text { Statistical analyses }}$}

First, a repeated measures ANOVA was applied to test specifically for changes over time within each treatment. The assumptions of normality and equal variance were satisfied. As the data from successive time points are likely not to be independent the covariance matrix the matrix of all covariances between time points - was examined. If that matrix was spherical (as confirmed by Mauchly's test of sphericity), then a standard repeated measures ANOVA calculation was carried out. If, however, the sphericity assumption did not hold, then the Greenhouse Geisser adjustment was applied (Greenhouse \& Geisser, 1959).

Repeated measures ANOVA was used to analyse effective quantum yield and $\mathrm{rETR}_{\max }$, with 'treatment' being the irradiance treatments and the different time points. The significance of differences between pairs of time points was adjusted using Bonferroni's correction. Finally, one-way ANOVA was used to compare the different treatment groups at specific time points. Post hoc tests using Bonferroni's correction were used for subsequent pair-wise comparisons, e.g. between different pairs of treatment groups at a time point, or between different time points within a treatment group. All differences referred to are statistically significant at $p<$ 0.05 . 
253 Effect of different light levels on the photosynthetic performance of Thalassiosira antarctica

254 (Ross Sea), Chaetoceros socialis (Antarctic Peninsula) and C. socialis (Arctic)

255 Initially a two way repeated measures ANOVA was conducted for all parameters with time as

256 the 'within' factor and treatment and species as 'between' factors (Table 1). This

257 demonstrated that both time alone and all the interaction combinations (excepting the three-

258 way time-treatment-species interaction on $E_{k}$ ) had a highly significant influence on each

259 parameter. Since the significant 3-way interactions make it impossible to interpret the

260 treatment effects, repeated measures analyses were carried out for each species separately to

261 test for the effect of all treatments and time.

Quantum Yield ( $\left.\phi_{P S I}\right)$

A repeated measures ANOVA was carried out for each species separately to test for effect of all treatments and time (Table 2). Although the general response, except for Chaetoceros socialis (Antarctic Peninsula) at L2, appeared to show consistent patterns over time, the repeated measures ANOVA for algae incubated at all light treatments was not significant for $\phi$ PSII Over $168 \mathrm{~h}$.

All the algal cultures showed no significant difference in quantum yield between those incubated in the dark (L0) or at ambient low light (L1) levels. For both the Antarctic species, quantum yield was lowest for algae incubated at L2 and highest for cultures incubated in the dark or at ambient light. For both species, quantum yield decreased significantly over the first two hours. However, quantum yield for T. antarctica at L2 did not show a significant change over $168 \mathrm{~h}$ while $C$. socialis showed an overall decrease. In the Arctic C. socialis, there was no overall change in quantum yield over $168 \mathrm{~h}$. However, at the end of the incubation, the quantum yield for the algae at ambient low light level was the highest and that of those in the 
dark and at the highest light exposure were the lowest. The general response for

followed by a recovery in $\phi$ PSII, then maintenance of a stable value over the rest of the incubation. Algae at L0 and L1 showed very little change over $168 \mathrm{~h}$. The general response for C. socialis (Antarctic Peninsula) (Figure 1(b)) at L0 and L1 was a slight increase followed by $\phi$ PSII remaining stable over $168 \mathrm{~h}$. For algae incubated at L2 and L3, there was a sharp decrease over the first $2 \mathrm{~h}$, followed by a recovery in $\phi$ PsI between 2 and $4 \mathrm{~h}$. However, algae at the higher light treatments of L2 and L3 then showed a gradual decrease in $\phi$ PSII to reach levels similar to those at $2 \mathrm{~h}$. Although the repeated measures ANOVA showed no significant change in $\phi_{\mathrm{PSII}}$ over $168 \mathrm{~h}$ for this species at L0, L1 and L3, those at L2 showed a significant decrease over the full $168 \mathrm{~h}$ period. C. socialis (Arctic Ocean) (Figure 1(c)) showed a gradual decrease in $\phi_{\text {PSII }}$ for algae incubated at L0 and a gradual increase for algae incubated at L1. Algae incubated at L2 showed an initial decrease in $\phi$ PSII followed by a recovery to reach the same levels as at the start of the incubation. Algae incubated at L3 also showed an initial decrease, but this was followed by a recovery to reach a $\phi_{\text {PSII }}$ lower than that at time $0 \mathrm{~h}$.

A repeated measures ANOVA was carried out for each species separately to test for effect of all treatments and time (Table 3). Although the general response showed changes over time, the repeated measures ANOVA showed no significant change in $\mathrm{rETR}_{\max }$ over $168 \mathrm{~h}$ for algae at all treatments, except for both Chaetoceros cultures at L2. an initial increase followed by rETRmax varying little throughout the incubation and not showing any change from time $0 \mathrm{~h}$. Algae at L0 showed a slight decrease in $\mathrm{rETR}_{\max }$ before it stabilized for the rest of the incubation. Algae incubated at L1 showed an increase in $\mathrm{rETR}_{\max }$ over the $168 \mathrm{~h}$. The general response of Chaetoceros socialis (Antarctic Peninsula) (Figure 
2(b)) for all light treatments other than at L0 was a slight increase in rETRmax followed by a decrease to reach a level higher than at time $0 \mathrm{~h}$. Algae at L0 did not show any change over time. Those incubated at L2 showed a significant increase in rETR $\max$ between 144 and 168 h. However, there was no overall significant increase. The general response of $C$. socialis (Arctic Ocean) (Figure 2(c)) for all light treatments other than at L0 was a slight increase in rETR $_{\max }$ followed by a decrease to reach a level similar to that at time $0 \mathrm{~h}$. Algae at L0 did not show any change over time. Algae incubated at L2 showed an overall significant increase in $\mathrm{rETR}_{\max }$.

\section{$\underline{\text { Chlorophyll } a}$}

Repeated measures ANOVA indicated a significant effect of time $(\mathrm{p}<0.005)$ and the interaction between time and species $(\mathrm{p}<0.005)$, but no significant interaction between time and light. However, Levene's test for equality of variances was significant at each time point, indicating that the data were highly variable. The chlorophyll data were, thus, too variable to permit conclusions to be drawn about the responses of the algae.

\section{$\underline{\text { Superoxide dismutase }}$}

Two way repeated measures ANOVA conducted with time as the 'within' factor and treatment and species as 'between' factors identified significant 3-way interactions. Repeated measures analyses were, therefore, carried out for each species separately to test for the effect of all treatments and time (Table 4).

Although the general responses appeared to show small and consistent patterns of change over time, the repeated measures ANOVA showed no significant change in SOD activity over $168 \mathrm{~h}$ for algae at all light treatments, except for Chaetoceros socialis (Antarctic Peninsula) which had a significant increase in the first $48 \mathrm{~h}$ for all light treatments followed by a significant decrease by $168 \mathrm{~h}$, resulting in no overall change over $168 \mathrm{~h}$. 
The general response of Thalassiosira antarctica (Ross Sea) (Figure 3(a)) in the dark and at low light levels was an increase in SOD activity. At the two higher light levels, SOD activity increased over the first $48 \mathrm{~h}$, followed by a decrease by the end of the incubation at $168 \mathrm{~h}$. The general response of Chaetoceros socialis (Antarctic Peninsula) (Figure 3(b)) at all light levels was an increase in SOD activity over the first $48 \mathrm{~h}$, followed by a decrease to reach a similar level at $168 \mathrm{~h}$ to that at the start of the incubation. That of C. socialis (Arctic Ocean) (Figure 3(c)) for all light treatments was a large decrease in SOD activity over the first $48 \mathrm{~h}$, followed by a slight recovery by $168 \mathrm{~h}$.

\section{Discussion}

Each of the species studied here is a common member of ice algal communities from each of three regions with different patterns of environmental variation, namely the Ross Sea, the Antarctic Peninsula and the Arctic Ocean. In the western Antarctic Peninsula (WAP) region, diatoms respond positively to increase in irradiance, with the effect being modulated by cell volume (Vernet et al., 2008). Although there has been a decrease in summer sea ice in this region leading to a decrease in phytoplankton blooms containing large, chain-forming diatoms (Garibotti et al., 2005), flagellate blooms are still able to maintain daily productivity (Vernet et al., 2008). These species-specific tolerances emphasise the variability that could be observed in environmentally similar regions with varying community composition.

In terms of the response of quantum yield to exposure to different light levels, differences between the same species from different regions could indicate specialization according to the niche they occupy. Species-specific sensitivities to environmental change have been observed elsewhere, suggesting that there is a link between photosynthetic capacity and ecological niche occupancy (Petrou \& Ralph, 2011). 
The combinations of PAR and UV-B exposures used, which mimic those that might reasonably be expected in the natural environment, mean that it is difficult to differentiate why a lack of change in quantum yield was observed at the higher light exposures. These exposures combine two parameters that are complementary to each other in the natural ecosystem, giving a better indication of how algae may tolerate increased radiation levels during summer and/or due to thinner sea ice conditions. The failure to find detectable levels of MAA production may indicate that MAAs are not amongst the mechanisms used by these algal species for photo-protection, unlike Rajanahally et al.'s (2014) clear demonstration of MAA production in experimental exposures of mixed multi-species algal communities soon after collection in the field in the same region of the Ross Sea used to source one of the cultures used here.

When the three species were compared at each light level, there was no significant change in quantum yield for algae incubated in the dark or at ambient low light, while those incubated at higher light exposures showed an overall significant decrease. At both higher light levels, the Arctic culture of $C$. socialis had the highest quantum yield at $168 \mathrm{~h}$, perhaps indicating a better ability to tolerate higher light exposure. During ice melt, algae are obviously exposed to both varying and/or increasing levels of light and other parameters which are more complex than those used in the current study. Van de Poll et al. (2009), studying the Antarctic marine diatom Chaetoceros brevis, identified no difference in growth rates of algae exposed to constant or dynamic irradiance regimes in iron-limited or replete conditions. Iron limitation and wind-driven vertical mixing that resulted in a dynamic irradiance regime were frequently co-occurring conditions that affected photosynthetic health of algae. However, their study identified differences in pigment composition, quantum yield and antioxidant capacity between algae exposed to the two irradiance regimes. Cellular pigment concentrations increased three-fold under dynamic as compared to constant irradiance, under 
iron-replete conditions. In iron-limited conditions smaller differences were detected in cellular pigment concentrations between the two regimes, suggesting reduced acclimation potential.

In the current study, the Arctic cultures had the highest SOD activity and the two Antarctic cultures showed equal activity at the start of all incubations. At all light exposures, the SOD activity did not show a difference between treatments at $168 \mathrm{~h}$. This lack of variation in SOD production at the different light treatments was unexpected (cf. Janknegt et al., 2009; Van de Poll et al., 2009), with algae incubated at the higher light levels predicted to express greater activity. It is possible that even the higher irradiance exposures used in this study were not high enough to cause stress in these algal cultures. Other studies that have observed oxidative stress have often used irradiances exceeding $1000 \mu \mathrm{mol} \mathrm{m}^{-2} \mathrm{~s}^{-1}$ (Van de Poll \& Buma, 2009). Janknegt et al. (2009), conversely, found that SOD activity in some microalgae decreased with exposure to high irradiance. An increase in the de-epoxidation of the xanthophyll pigments led to more efficient recovery of PS II and reduced the production of hydrogen peroxide, in turn reducing the need for production of SOD. The variation in SOD activity was correlated with the cell size of the species examined, with those that had a higher surface area to volume ratio showing an increase in SOD activity whereas those with lower ratio showed a decrease. In the species examined in the current study, C. socialis cells are known to be smaller than those of T. antarctica. SOD activity in C. socialis from the Arctic (but not the Antarctic Peninsula) was higher than that of $T$. antarctica. The difference in SOD activity between cultures of $C$. socialis obtained from the Antarctic Peninsula and the Arctic could be related to the degree of change in the two regions, although to confirm this would require detailed measuring and experimental studies of cultures obtained from multiple locations.

This study took place over a one week manipulation period in order to examine any effect of length of incubation on acclimatory abilities. For all three species, there were very few 
significant changes in photosynthetic parameters between 2 and $7 \mathrm{~d}$, which strongly supports the utility of shorter incubation periods in experimental studies of this type. In the natural environment, the time taken for sea ice to melt can vary considerably and is influenced by various factors such as snow cover and initial thickness (Thomas \& Dieckmann, 2003).

In this study, the combination of exposure to PAR and UV-B led to a lack of differentiation in algal photosynthetic health, contrasting with the significant effects on photosynthetic parameters and MAA production that was previously observed in monospecific Ross Sea cultures when subjected to increases in PAR or UV-B separately (Rajanahally, 2014). During and after sea ice melt, algae face increases in PAR, UV-B and temperature and decreases in salinity, and the consequences of these effects cannot be estimated simply in an additive fashion (Folt et al., 1999). These responses will be further complicated by responses to changing $\mathrm{CO}_{2}$ concentrations and ocean acidification processes (e.g. Gao et al., 2012, Rost et al., 2006). It is therefore essential for multivariate studies to be conducted that combine as many of these factors as possible in order to give insight into how algae tolerate the entirety of the processes of ice melt and release into the pelagic environment. Studies including evaluation of the photo-protective responses of these algae, such as that described here, will help assess their ability to survive current and predicted magnitudes of climate change and, hence, assess risks to the productivity of these ice-covered regions of the global oceans.

\section{Acknowledgements}

We acknowledge support from VUW grant 100241, and FRST Grant VICX0706. MAF permits 2009037596 and 2010040450 were used to transport cultures and samples from Antarctica to New Zealand. We thank Antarctica New Zealand for logistic support in the field. Dr. Claire Hughes and Assoc. Prof. Else Hegspeth are thanked for the provision of 
cultures originally obtained from the Antarctic Peninsula and Arctic Ocean. Two anonymous reviewers are thanked for constructive comments. PC is supported by NERC core funding to the BAS Biodiversity, Evolution and Adaptation programme. This paper also contributes to the SCAR AnT-ERA international science programme.

\section{References}

Arrigo, K. R., C. W. Sullivan \& J. N. Kremer, 1991. A bio-optical model of Antarctic sea ice. Journal of Geophysical Research: Oceans 96: 10581-10592.

Arrigo, K. R. \& D. N. Thomas, 2004. Large scale importance of sea ice biology in the Southern Ocean. Antarctic Science 16: 471-486.

Arrigo, K. R., T. Mock \& M. P. Lizotte, 2010. Primary Producers and Sea Ice. In Thomas, D. N. \& G. S. Dieckmann (Eds.), Sea Ice (Second edition), Blackwell Publishing Ltd, Oxford: 283-325.

Arrigo, K. R., D. K. Perovich, R. S. Pickart, Z. W. Brown, G. L. van Dijken, K. E. Lowry et al., 2012. Massive phytoplankton blooms under Arctic sea ice. Science 336: 14081408.

Arrigo, K. R. 2014. Sea ice ecosystems. Annual Review of Marine Science 6: 439-467.

Beauchamp, C. \& I. Fridovich, 1971. Superoxide dismutase: Improved assays and an assay applicable to acrylamide gels. Analytical Biochemistry 44: 276-287.

Beyer, W. F. \& I. Fridovich, 1987. Assaying for superoxide dismutase activity: Some large consequences for minor changes in conditions. Analytical Biochemistry 161: 559566. 
445 Cunningham, W.L. \& A. Leventer, 1998. Diatom assemblages in surface sediments of the Ross Sea: relationship to present oceanographic conditions. Antarctic Science 10:

447 $134-146$.

448

Davidson, A. T., D. Bramich, H. J., Marchant \& A. McMinn, 1994. Effects of UV-B irradiation on growth and survival of Antarctic marine diatoms. Marine Biology 119: $507-515$

Eicken, H. 1992. The role of sea ice in structuring Antarctic ecosystems. Polar Biology 12: 313.

Evans, C. A., J. E. O'Reilly \& J. P. Thomas, 1987. A handbook for the measurement of chlorophyll $a$ and primary production. Texas A\&M University, College Station.

Folt, C. L., C. Y. Chen, M. V. Moore \& J. Burnaford, 1999. Synergism and antagonism among multiple stressors. Limnology and Oceanography 44: 864-877.

Fryer, M. J., J. R. Andrews, K. Oxborough, D. A. Blowers \& R. Baker, 1998. Relationship between $\mathrm{CO}_{2}$ assimilation, photosynthetic electron transport, and active $\mathrm{O}_{2}$ metabolism in leaves of maize in the field during periods of low temperature. Plant Physiology 116: 571-580.

Gao, K., J. Xu, G. Gao, Y. Li, D. A. Hutchins, B. Huang, L. Wang, Y. Zheng, P. Jin, X. Cai, D-P. Hader, W. Li, K. Xu, N. Liu \& U. Riebesell, 2012. Rising $\mathrm{CO}_{2}$ and increased light exposure synergistically reduce marine primary productivity. Nature Climate Change 2: 519-523.

Garibotti, I. A., M. Vernet \& M. E. Ferrario, 2005. Annually recurrent phytoplanktonic assemblages during summer in the seasonal ice zone west of the Antarctic Peninsula (Southern Ocean). Deep Sea Research Part I: Oceanographic Research Papers 52: 1823-1841. 
469 Greenhouse, S.W. \& S. Geisser, 1959. On methods in the analysis of profile data. Psychometrika 24: 95-112.

471

Gregory, E. M., \& I. Fridovich, 1973. Induction of superoxide dismutase by molecular oxygen. Journal of Bacteriology 114: 543-548.

Halac, S., E. Garcia-Mendoza \& A. T. Banaszak, 2009. Ultraviolet radiation reduces the photoprotective capacity of the marine diatom Phaeodactylum tricornutum (Bacillariophyceae, Heterokontophyta). Photochemistry and Photobiology 85: 807815.

Halac, S. R., V. E. Villafañe \& E. W. Helbling, 2010. Temperature benefits the photosynthetic performance of the diatoms Chaetoceros gracilis and Thalassiosira weissflogii when exposed to UVR. Journal of Photochemistry and Photobiology B: Biology 101: 196-205.

Hancke, K., T. B. Hancke, L. M. Olsen, G. Johnsen \& R. N. Glud, 2008. Temperature effects on microalgal photosynthesis-light responses measured by $\mathrm{O}_{2}$ production, pulseamplitude-modulated fluorescence, and ${ }^{14} \mathrm{C}$ assimilation. Journal of Phycology 44: $501-514$

Hannach, G. \& A. C. Sigleo, 1998. Photoinduction of UV-absorbing compounds in six species of marine phytoplankton. Marine Ecology Progress Series 174: 207-222.

Harrison, W. G. \& G. F. Cota, 1991. Primary production in polar waters: relation to nutrient availability. Polar Research 10: 87-104.

Janknegt, P. J., J. W. Rijstenbil, W. H. van de Poll, T. S. Gechev \& A. G. J. Buma, 2007. A comparison of quantitative and qualitative superoxide dismutase assays for application to low temperature microalgae. Journal of Photochemistry and Photobiology B: Biology 87: 218-226. 
Janknegt, P. J., C. M. de Graaff, W. H. van de Poll, R. J. W. Visser, J. W. Rijstenbil \& A. G. J. Buma, 2009. Short-term antioxidative responses of 15 microalgae exposed to excessive irradiance including ultraviolet radiation. European Journal of Phycology 44: 525-539.

Katayama, T. \& S. Taguchi, 2013. Photoprotective responses of an ice algal community in Saroma-Ko Lagoon, Hokkaido, Japan. Polar Biology 36: 1431-1439.

Leu, E., S.-Å. Wängberg, A. Wulff, S. Falk-Petersen, J. Børre Ørbæk \& D. O. Hessen, 2006. Effects of changes in ambient PAR and UV radiation on the nutritional quality of an Arctic diatom (Thalassiosira antarctica var. borealis). Journal of Experimental Marine Biology and Ecology 337: 65-81.

Leu, E., J. Wiktor, J. E. Søreide, J. Berge \& S. Falk-Petersen, 2010. Increased irradiance reduces food quality of sea ice algae. Marine Ecology Progress Series 411: 49-60.

Lund-Hansen, L. C., I. Hawes, B. K. Sorrell \& M. H. Nielsen, 2013. Removal of snow cover inhibits spring growth of Arctic ice algae through physiological and behavioral effects. Polar Biology 37: 471-481.

Majewska, R., M.C. Gambi, C.M. Totti \& M. De Stefano, 2013. Epiphytic diatom communities of Terra Nova Bay (Ross Sea, Antarctica): structural analysis and relations to algal host. Antarctic Science 25: 501-513.

Maksym, T., S. E. Stammerjohn, S. Ackley \& R. Massom, 2012. Antarctic sea ice - A polar opposite? Oceanography 25: 140-151.

Mangoni, O., M. Saggiomo, M., Modigh, G. Catalano, A. Zingone \& V. Saggiomo, 2009. The role of platelet ice microalgae in seeding phytoplankton blooms in Terra Nova Bay (Ross Sea, Antarctica): a mesocosm experiment. Polar Biology 32: 311-323.

Martin, A., A. McMinn, M. Heath, E. N. Hegseth \& K. G. Ryan, 2012. The physiological response to increased temperature in over-wintering sea ice algae and phytoplankton 

in McMurdo Sound, Antarctica and Tromso Sound, Norway. Journal of Experimental Marine Biology and Ecology 428: 57-66.

McMinn, A. \& E. N. Hegseth, 2004. Quantum yield and photosynthetic parameters of marine microalgae from the southern Arctic Ocean, Svalbard. Journal of the Marine Biological Association of the United Kingdom 84: 865-871.

Mundy, C., M. Gosselin, J. Ehn, C. Belzile, M. Poulin, E. Alou et al. 2011. Characteristics of two distinct high-light acclimated algal communities during advanced stages of sea ice melt. Polar Biology 34: 1869-1886.

Nicol, S., J. Clarke, S. J. Romaine, S. Kawaguchi, G. Williams \& G. W. Hosie, 2008. Krill (Euphausia superba) abundance and Adélie penguin (Pygoscelis adeliae) breeding performance in the waters off the Béchervaise Island colony, East Antarctica in 2 years with contrasting ecological conditions. Deep Sea Research Part II: Topical Studies in Oceanography 55: 540-557.

Parkhill, J.-P., G. Maillet \& J. J. Cullen, 2001. Fluorescence-based maximal quantum yield for PSII as a diagnostic of nutrient stress. Journal of Phycology 37: 517-529.

Petrou, K., S. A. Kranz, M. A. Doblin \& P. J. Ralph, 2011. Photophysiological responses of Fragilariopsis cylindrus (Bacillariophyceae) to nitrogn depletion at two temperatures. Journal of Phycology 48: 127-136.

Petrou, K. \& P. Ralph, 2011. Photosynthesis and net primary productivity in three Antarctic diatoms: possible significance for their distribution in the Antarctic marine ecosystem. Marine Ecology Progress Series 437: 27-40.

van de Poll, W. H., M. A. van Leeuwe, J. Roggeveld \& A. G. J. Buma, 2005. Nutrient limitation and high irradiance acclimation reduce PAR and UV-induced viability loss in the Antarctic diatom Chaetoceros brevis (Bacillariophyceae). Journal of Phycology 41: $840-850$. 
van de Poll, W. H. \& A. G. J. Buma, 2009. Does ultraviolet radiation affect the xanthophyll cycle in marine phytoplankton? Photochemical and Photobiological Sciences 8: 12951301.

van de Poll, W. H., P. J. Janknegt, M. A. van Leeuwe, R. J. W. Visser \& A. G. J. Buma, 2009. Excessive irradiance and antioxidant responses of an Antarctic marine diatom exposed to iron limitation and to dynamic irradiance. Journal of Photochemistry and Photobiology B: Biology 94: 32-37.

Rajanahally, M.A. 2014. Antarctic microalgae: physiological acclimation to environmental change. MSc Thesis, Victoria University of Wellington, Wellington.

Rajanahally, M.A., D. Sim, K. G. Ryan \& P. Convey, 2014. Can bottom ice algae tolerate irradiance and temperature changes? Journal of Experimental Marine Biology and Ecology 461: 516-527

Ralph, P.J. \& R. Gademann, 2005. Rapid light curves: A powerful tool to assess photosynthetic activity. Aquatic Botany 82, 222-237.

Ratkova, T. N., A. F. Sazhin \& K. N. Kosobokova, 2004. Unicellular inhabitants of the White Sea underice pelagic zone during the early spring period. Oceanology 44: 240-246.

Riebesell, U., I. Schloss \& V. Smetacek, 1991. Aggregation of algae released from melting sea ice: implications for seeding and sedimentation. Polar Biology 11: 239-248.

Ritchie, R., 2008. Fitting light saturation curves measured using modulated fluorometry. Photosynthesis Research 96: 201-215.

Rost, B., U. Riebesell \& D. Sultemeyer, 2006. Carbon acquisition of marine phytoplankton: Effect of photoperiod length. Limnology and Oceanography 51: 12-20.

Ryan, K. G., A. McMinn, K. A. Mitchell \& L. Trenerry, 2002. Mycosporine-like amino acids in Antarctic sea ice algae, and their response to UVB radiation. Zeitschrift fur Naturforschung 57: 471-477. 
Ryan, K. G., R. O. M. Cowie, E. Liggins, D. McNaughtan, A. Martin \& S. K. Davy, 2009. The short-term effect of irradiance on the photosynthetic properties of antarctic fastice microalgal communities. Journal of Phycology 45: 1290-1298.

Ryan, K. G., M. L. Tay, A. Martin, A., McMinn \& S. K. Davy, 2011. Chlorophyll fluorescence imaging analysis of the responses of Antarctic bottom-ice algae to light and salinity during melting. Journal of Experimental Marine Biology and Ecology 399: $156-161$.

Ryan, K. G., A. McMinn, E. N. Hegseth \& S. K. Davy, 2012. The effects of ultraviolet-B radiation on Antarctic sea-ice algae. Journal of Phycology 48: 74-84.

Rysgaard, S., M. Kuhl, R. N. Glud \& J. W. Hansen, 2001. Biomass, production and horizontal patchiness of sea ice algae in a high-Arctic fjord (Young Sound, NE Greenland). Marine Ecology Progress Series 223: 15-26.

Salleh, S. \& A. McMinn, 2011. Photosynthetic response and recovery of Antarctic marine benthic microalgae exposed to elevated irradiances and temperatures. Polar Biology 34: $855-869$.

SooHoo, J. B., A. C. Palmisano, S. T. Kottmeier, M. P. Lizotte, S. L. SooHoo \& C. W. Sullivan, 1987. Spectral light absorption and quantum yield of photosynthesis in sea ice microalgae and a bloom of Phaeocystis pouchetii from McMurdo Sound, Antarctica. Marine Ecology Progress Series 39: 175-189.

Stammerjohn, S., R. Massom, D. Rind \& D. Martinson, 2012. Regions of rapid sea ice change: An inter-hemispheric seasonal comparison. Geophysical Research Letters 39.

Thomas, D. N. \& G. S. Dieckmann, 2003. Sea ice: An introduction to its physics, chemistry, biology and geology, Wiley-Blackwell, Oxford.

Turner, J., N. E. Barrand, T. J. Bracegirdle, P. Convey, D.A. Hodgson, M. Jarvis et al. 2013. Antarctic climate change and the environment: an update. Polar Record 50: 237-259. 
593 Vernet, M., D. Martinson, R. Iannuzzi, S. Stammerjohn, W. Kozlowski, K. Sines et al. 2008. 594 Primary production within the sea-ice zone west of the Antarctic Peninsula: Sea ice,

595 summer mixed layer, and irradiance. Deep Sea Research Part II: Topical Studies in

596 Oceanography 55: 2068-2085.

597 Zor, T. \& Z. Selinger, 1996. Linearization of the Bradford protein assay increases its

598 sensitivity: Theoretical and experimental studies. Analytical Biochemistry 236: 302-

599 308.

600 
Table 1. Summary of results of statistical analyses of changes in quantum yield of photosystem II, rETRmax, Alpha $(\alpha)$ and $E_{\mathrm{k}}$ for Thalassiosira antarctica (Ross Sea), Chaetoceros socialis (Antarctic Peninsula) and C. socialis (Arctic) over $168 \mathrm{~h}$ experimental treatments at different combinations of PAR and UV-B levels ( $\mathrm{L} 0=0$ $\mu \mathrm{mol} \mathrm{m} \mathrm{s}^{-2}$; L1 $=1 \mu \mathrm{mol} \mathrm{m} \mathrm{m}^{-2} \mathrm{~s}^{-1}$ L $2=45 \mu \mathrm{mol} \mathrm{m} \mathrm{m}^{-2} \mathrm{~s}^{-1}$ and $50 \mathrm{mWm}^{-2} ; \mathrm{L} 3=100 \mu \mathrm{mol}$ $\mathrm{m}^{-2} \mathrm{~s}^{-1}$ and $100 \mathrm{mWm}^{-2}$ ) at $4^{\circ} \mathrm{C}$, analysed using repeated measures ANOVA. Detailed analyses are presented in Tables 2 and 3.

\begin{tabular}{|lcccc|}
\hline Source of variation & Time & Time x Treatments & Time x Species & Time x Treatments x Species \\
\hline 申PSII & $<0.001$ & $<0.001$ & $<0.001$ & $<0.001$ \\
& & & & \\
$\mathbf{r E T R}_{\text {max }}$ & $<0.001$ & $<0.001$ & $<0.001$ & $<0.001$ \\
& & & & $<0.001$ \\
$\mathbf{A l p h a}(\boldsymbol{\alpha})$ & $<0.001$ & $<0.001$ & $<0.001$ & \\
& & & & 0.064 \\
$\boldsymbol{E}_{\mathbf{k}}$ & 0.002 & $<0.001$ & 0.001 & \\
\hline
\end{tabular}


Table 2. Changes in quantum yield of photosystem II over $168 \mathrm{~h}$ experimental treatments at different combinations of PAR and UV-B levels (L $0=0 \mu \mathrm{mol} \mathrm{m}^{-2} \mathrm{~s}^{-1}$; $\mathrm{L} 1=1 \mu \mathrm{mol} \mathrm{m} \mathrm{m}^{-2} \mathrm{~s}^{-1} ; \mathrm{L} 2=45 \mu \mathrm{mol} \mathrm{m} \mathrm{m}^{-2} \mathrm{~s}^{-1}$ and $50 \mathrm{mWm}^{-2} ; \mathrm{L} 3=100 \mu \mathrm{mol} \mathrm{m} \mathrm{m}^{-2} \mathrm{~s}^{-1}$ and 100 $\mathrm{mWm}^{-2}$ ) at $4^{\circ} \mathrm{C}$, analysed using repeated measures ANOVA. Significant changes identified by post hoc pairwise analyses are also listed.

\begin{tabular}{|c|c|c|c|c|c|}
\hline Source of variation & df & MS & $F$ & $\mathrm{p}$ & post hoc comparisons \\
\hline \multicolumn{6}{|c|}{ Thalassiosira antarctica (Ross Sea) } \\
\hline \multicolumn{6}{|l|}{ Within subjects } \\
\hline Time & 2.340 & 0.072 & 54.188 & $<0.001$ & \multirow{3}{*}{$\begin{array}{l}\text { No change over } 168 \mathrm{~h} \\
\text { (see text for details) }\end{array}$} \\
\hline Time $\mathrm{x}$ Treatments & 7.021 & 0.027 & 20.116 & $<0.001$ & \\
\hline Error & 18.723 & 0.001 & & & \\
\hline \multicolumn{6}{|l|}{ Between subjects } \\
\hline Treatments & 3 & 0.479 & 91.685 & $<0.001$ & $(\mathrm{~L} 0=\mathrm{L} 1)>\mathrm{L} 3>\mathrm{L} 2$ \\
\hline Error & 8 & 0.005 & & & \\
\hline \multicolumn{6}{|c|}{ Chaetoceros socialis (Antarctic Peninsula) } \\
\hline \multicolumn{6}{|l|}{ Within subjects } \\
\hline Time & 4.325 & 0.034 & 41.242 & $<0.001$ & \multirow{3}{*}{$\begin{array}{l}\text { Decrease over } 168 \mathrm{~h} \\
\text { (see text for details) }\end{array}$} \\
\hline Time $\mathrm{x}$ Treatments & 12.974 & 0.029 & 34.796 & $<0.001$ & \\
\hline Error & 34.597 & 0.001 & & & \\
\hline \multicolumn{6}{|l|}{ Between subjects } \\
\hline Treatments & 3 & 0.687 & 143.726 & $<0.001$ & $(\mathrm{~L} 0=\mathrm{L} 1)>\mathrm{L} 3>\mathrm{L} 2$ \\
\hline Error & 8 & 0.003 & & & \\
\hline \multicolumn{6}{|c|}{ C. socialis (Arctic Ocean) } \\
\hline \multicolumn{6}{|l|}{ Within subjects } \\
\hline Time & 3.249 & 0.074 & 67.017 & $<0.001$ & No change over $168 \mathrm{~h}$ \\
\hline Time $\mathrm{x}$ Treatments & 9.746 & 0.029 & 26.218 & $<0.001$ & (see text for details) \\
\hline Error & 25.991 & 0.001 & & & \\
\hline \multicolumn{6}{|l|}{ Between subjects } \\
\hline Treatments & 3 & 0.329 & 78.456 & $<0.001$ & $\mathrm{~L} 1>(\mathrm{L} 0=\mathrm{L} 3)>\mathrm{L} 2$ \\
\hline Error & 8 & 0.004 & & & \\
\hline
\end{tabular}


Table 3. Changes in rETR $\max$ of photosystem II over $168 \mathrm{~h}$ experimental treatments at different combinations of PAR and UV-B levels ( $\mathrm{L} 0=0 \mu \mathrm{mol} \mathrm{m}{ }^{-2} \mathrm{~s}^{-1} ; \mathrm{L} 1=1 \mu \mathrm{mol} \mathrm{m}{ }^{-2}$ $\mathrm{s}^{-1}$; L2 $=45 \mu \mathrm{mol} \mathrm{m}^{-2} \mathrm{~s}^{-1}$ and $50 \mathrm{mWm}^{-2}$; L3 $=100 \mu \mathrm{mol} \mathrm{m}^{-2} \mathrm{~s}^{-1}$ and $100 \mathrm{mWm}^{-2}$ ) at $4^{\circ} \mathrm{C}$, analysed using repeated measures ANOVA. Significant changes identified by post hoc pairwise analyses are also listed.

\begin{tabular}{|c|c|c|c|c|c|}
\hline Source of variation & $\mathrm{df}$ & MS & $F$ & $\mathrm{p}$ & post hoc comparisons \\
\hline \multicolumn{6}{|c|}{ Thalassiosira antarctica (Ross Sea) } \\
\hline \multicolumn{6}{|l|}{ Within subjects } \\
\hline Time & 1.755 & 707.828 & 43.814 & $<0.001$ & \multirow{3}{*}{$\begin{array}{l}\text { No change over } 168 \mathrm{~h} \\
\text { (see text for details) }\end{array}$} \\
\hline Time $\mathrm{x}$ Treatments & 5.266 & 229.137 & 14.184 & $<0.001$ & \\
\hline Error & 14.043 & 16.155 & & & \\
\hline \multicolumn{6}{|l|}{ Between subjects } \\
\hline Treatments & 3 & 703.075 & 149.478 & $<0.001$ & \multirow[t]{2}{*}{$\mathrm{L} 1>\mathrm{L} 2>\mathrm{L} 3>\mathrm{L} 0$} \\
\hline Error & 8 & 4.704 & & & \\
\hline \multicolumn{6}{|c|}{ Chaetoceros socialis (Antarctic Peninsula) } \\
\hline \multicolumn{6}{|l|}{ Within subjects } \\
\hline Time & 2.824 & 157.000 & 38.798 & $<0.001$ & \multirow{3}{*}{$\begin{array}{l}\text { No change over } 168 \mathrm{~h} \\
\text { (see text for details) }\end{array}$} \\
\hline Time $\mathrm{x}$ Treatments & 8.471 & 82.856 & 20.475 & $<0.001$ & \\
\hline Error & 22.590 & 4.047 & & & \\
\hline \multicolumn{6}{|l|}{ Between subjects } \\
\hline Treatments & 3 & 489.269 & 119.725 & $<0.001$ & $\mathrm{~L} 1>\mathrm{L} 2>\mathrm{L} 3>\mathrm{L} 0$ \\
\hline Error & 8 & 4.087 & & & \\
\hline \multicolumn{6}{|c|}{ C. socialis (Arctic Ocean) } \\
\hline \multicolumn{6}{|l|}{ Within subjects } \\
\hline Time & 2.929 & 620.532 & 283.378 & $<0.001$ & Increase over $168 \mathrm{~h}$ \\
\hline Time $\mathrm{x}$ Treatments & 8.786 & 78.510 & 35.853 & $<0.001$ & (see text for details) \\
\hline Error & 23.429 & 2.190 & & & \\
\hline \multicolumn{6}{|l|}{ Between subjects } \\
\hline Treatments & 3 & 670.216 & 82.660 & $<0.001$ & $\mathrm{~L} 2>(\mathrm{L} 1=\mathrm{L} 3)>\mathrm{L} 0$ \\
\hline Error & 8 & 8.108 & & & \\
\hline
\end{tabular}


Table 4. Changes in SOD activity over $168 \mathrm{~h}$ experimental treatments at different combinations of PAR and UV-B levels (L0 $=0 \mu \mathrm{mol} \mathrm{m}^{-2} \mathrm{~s}^{-1} ; \mathrm{L} 1=1 \mu \mathrm{mol} \mathrm{m} \mathrm{m}^{-2} \mathrm{~s}^{-1}$; $\mathrm{L} 2=45 \mu \mathrm{mol} \mathrm{m}{ }^{-2} \mathrm{~s}^{-1}$ and $50 \mathrm{mWm}^{-2}$; L3 $=100 \mu \mathrm{mol} \mathrm{m}^{-2} \mathrm{~s}^{-1}$ and $100 \mathrm{mWm}^{-2}$ ) at $4^{\circ} \mathrm{C}_{\text {, }}$ analysed using repeated measures ANOVA. Significant changes identified by post hoc pairwise analyses are also listed.

\begin{tabular}{|c|c|c|c|c|c|}
\hline Source of variation & $\mathrm{df}$ & MS & $F$ & $\mathrm{p}$ & post hoc comparisons \\
\hline \multicolumn{6}{|c|}{ Thalassiosira antarctica (Ross Sea) } \\
\hline \multicolumn{6}{|l|}{ Within subjects } \\
\hline Time & 2 & 55299.731 & 3.817 & 0.044 & \multirow{3}{*}{$\begin{array}{l}\text { No change over } 168 \mathrm{~h} \\
\text { (see text for details) }\end{array}$} \\
\hline Time $\mathrm{x}$ Treatments & 6 & 23650.055 & 1.632 & 0.202 & \\
\hline Error & 16 & 14488.0404 & & & \\
\hline \multicolumn{6}{|l|}{ Between subjects } \\
\hline Treatments & 3 & 35853.695 & 2.271 & 0.157 & \multirow[t]{2}{*}{$\mathrm{L} 0=\mathrm{L} 1=\mathrm{L} 2=\mathrm{L} 3$} \\
\hline Error & 8 & 15790.600 & & & \\
\hline \multicolumn{6}{|c|}{ Chaetoceros socialis (Antarctic Peninsula) } \\
\hline \multicolumn{6}{|l|}{ Within subjects } \\
\hline Time & 2 & 326604.643 & 23.878 & $<0.001$ & \multirow{3}{*}{$\begin{array}{l}\text { No change over } 168 \mathrm{~h} \\
\text { (see text for details) }\end{array}$} \\
\hline Time $\mathrm{x}$ Treatments & 6 & 18888.579 & 1.381 & 0.281 & \\
\hline Error & 16 & 13677.826 & & & \\
\hline \multicolumn{6}{|l|}{ Between subjects } \\
\hline Treatments & 3 & 11406.406 & 0.588 & 0.640 & $\mathrm{~L} 0=\mathrm{L} 1=\mathrm{L} 2=\mathrm{L} 3$ \\
\hline Error & 8 & 19382.839 & & & \\
\hline \multicolumn{6}{|c|}{ C. socialis (Arctic Ocean) } \\
\hline \multicolumn{6}{|l|}{ Within subjects } \\
\hline Time & 1.255 & 1307937.01 & 47.731 & $<0.001$ & Decrease over $168 \mathrm{~h}$ \\
\hline Time $\mathrm{x}$ Treatments & 3.766 & 16582.805 & 0.605 & 0.659 & (see text for details) \\
\hline Error & 10.042 & 27402.151 & & & \\
\hline \multicolumn{6}{|l|}{ Between subjects } \\
\hline Treatments & 3 & 12677.400 & 0.910 & 0.478 & $\mathrm{~L} 0=\mathrm{L} 1=\mathrm{L} 2=\mathrm{L} 3$ \\
\hline Error & 8 & 13924.998 & & & \\
\hline
\end{tabular}

